\title{
Cultural perceptions and natural protections: a socio-legal analysis of public participation, birdlife and Ramsar Wetlands in Japan
}

\author{
Evan Hamman* \\ Lecturer, Faculty of Law, Queensland University of Technology
}

The aim of this article is better to understand the relationship Japanese people have with birdlife, wetlands and environmental law. The article uses a case study of the Japanese 'red-crowned' crane (the tancho) and Ramsar sites in Eastern Hokkaido to examine Japan's environmental governance systems and actors and the extent to which they utilize the principle of public participation. The topic is significant because of the urgency with which wetlands and birdlife are being lost in East Asia and the impacts such loss will have on communities and national identity. The observations in this article have relevance for neighbouring Asian countries like China and Korea, both of which have their own cultural perceptions and legal protections to consider.

Keywords: Ramsar, wetlands, public participation, tancho, red-crowned crane, Japan

\section{INTRODUCTION}

Wetlands play a vital role in the health of ecosystems and communities. They have functional significance for the entire hydrological cycle, ${ }^{1}$ and provide safe havens for birds and other biodiversity. The value to humans of wetlands has also been recognized in the Millennium Ecosystem Assessment (MEA) as an important source of agriculture, fishing and recreational pursuits like hiking and tourism. ${ }^{2}$ Legal protections for wetlands and dependent wildlife exist internationally; principally through agreements like the Convention on Wetlands of International Importance (Ramsar), ${ }^{3}$

* The author would like to thank the editor and the anonymous reviewer on this paper each of whom provided helpful comments on how the paper might be improved. An earlier draft of this paper was presented at a workshop in April 2017 at the Chinese University of Hong Kong (CUHK) Faculty of Law. The author is grateful for comments provided at that workshop, in particular from Professors Alexander Zahar (Wuhan University), Ben Boer (Wuhan University), Benoit Mayer (CUHK) and Yuhong Zhao (CUHK). Any errors in this paper remain those of the author.

1. See Andy Bullock and Mike Acreman, 'The role of wetlands in the hydrological cycle' (2003) 7(3) Hydrology and Earth System Sciences 358.

2. Millennium Ecosystem Assessment, 'Ecosystems and Human Well-being: Wetlands and Water Synthesis’ (Island Press, 2005) <https://www.millenniumassessment.org/documents/ document.358.aspx.pdf $>$.

3. Convention on Wetlands of International Importance. Ramsar (Iran), 2 February 1971. UN Treaty Series No. 14583. 
the Convention on Migratory Species (the Bonn Convention) ${ }^{4}$ and the Convention on Biological Diversity (CBD). ${ }^{5}$

Despite these initiatives, the world's wetlands are in decline. ${ }^{6}$ As much as 70 per cent have been degraded over the course of the last century. ${ }^{7}$ Migratory waterbirds ${ }^{8}$ which rely on wetlands for safe haven have suffered considerably. ${ }^{9}$ Some species, such as cranes, have declined by up to 47 per cent from population levels recorded in the 1980s. ${ }^{10}$ In the Asia-Pacific region, the decline of waterbird populations has been particularly severe. ${ }^{11}$ The principal cause of wetland loss has been the clearing of land for drainage and agricultural development. ${ }^{12}$ Changes to migratory patterns of birdlife and population trends are directly impacted by these occurrences and the global phenomenon of climate change seems to be exacerbating degradation. ${ }^{13}$ The state of Australia's migratory shorebirds, for instance, many of which migrate to China, Korea and Japan, has fallen considerably over the last century. ${ }^{14}$ The declines have been attributed to disturbance of 'staging sites', for example through development in the East China Sea. ${ }^{15}$ Japan's birdlife are facing similar challenges, with over a dozen species (including kingfishers, wrens and herons) already declared extinct. ${ }^{16}$

The future impact of wetland degradation and loss of birdlife in Asia is uncertain. One crucial aspect to consider is the effect such loss will have on culture and national identity. Birds such as the red-crowned crane (tancho in Japanese) are revered in Asian countries like Japan, China and Korea. The red-crowned crane is a symbol

4. The Convention on the Conservation of Migratory Species of Wild Animals [1979] 1651 UNTS 333.

5. Convention on Biological Diversity, [1993] ATS 32 / 1760 UNTS 79 / 31 ILM 818 (1992).

6. See Nick Davidson, 'How much wetland has the world lost? Long-term and recent trends in global wetland area' (2014) 65(1) Marine and Freshwater Research 934.

7. Royal Gardner, Stefano Barchiesi, Coralie Beltrame, Max Finlayson, Thomas Galewski, Ian Harrison, Marc Paganini, Christian Perennou, Dave Pritchard, Ake Rosenqvist and Matt Walpole 'State of the World's Wetlands and their Services to People: A compilation of recent analyses' (2015) Ramsar Briefing Note, 1.

8. Waterbirds are defined as 'birds ecologically dependent on wetlands' (see Art 1.2 of Ramsar).

9. See Curt Meine and George Archibald, The Cranes: - Status Survey and Conservation Action Plan (IUCN, Gland, Switzerland and Cambridge UK 1996).

10. Millennium Ecosystem Assessment (n 2) 29.

11. See Simon Delany, Szabolcs Nagy and Nick Davidson (eds), State of the World's Waterbirds 2010 (Wetlands International, Wageningen 2010).

12. Millennium Ecosystem Assessment (n 2) 40.

13. Christiaan Both, Sandra Bouwhuis, Kate Lessells and Marcel Visser, 'Climate change and population declines in a long-distance migratory bird' (2006) 441(7089) Nature 81.

14. For a discussion of the declines amongst specific populations, see Mike Bamford, Doug Watkins, Wes Bancroft, Gen Tischler and Johannes Wahl, Migratory Shorebirds of the East Asian - Australasian Flyway; Population Estimates and Internationally Important Sites (Wetlands International, Canberra, Australia 2008).

15. See for instance David Melville, Ying Chen and Zhijun Ma, 'Shorebirds along the Yellow Sea coast of China face an uncertain future - a review of threats' (2015) 116 Emu 100.

16. Ministry of the Environment, Government of Japan, 'State of Japan's Environment at a Glance: Extinct and Endangered Species Listed in the Red Data Book' <https://www.env.go. $\mathrm{jp} / \mathrm{en} /$ nature/biodiv/reddata.html $>$. 
of luck, loyalty and longevity in Japan. ${ }^{17}$ It forms the basis of the 'thousand paper crane' phenomenon (senbazuru), and is the symbol of Japan's national airline. In China, the red-crowned crane was recently nominated for national bird ${ }^{18}$ and has an auspicious and mythological presence in ancient Chinese society. In neighbouring Korea, the Hakmu ('crane dance') is a ceremonial dance first performed before King Sejong (1397-1450) and is still performed today. ${ }^{19}$

Emerging discourses in conservation and heritage tells us there is an unbreakable connection between nature and culture. ${ }^{20}$ Outdated and Eurocentric approaches (which tended to separate culture from nature) have been criticized for their artificiality and have been challenged for their effectiveness. The weight of the literature now suggests that culture and nature are intricately intertwined such that loss of nature can impact disastrously on the well-being of communities. The underlying premise of this paper is that the reverse proposition also holds true. That is, there is a central and vital role for communities - through their culture - to protect and conserve the natural world. As Gillespie rightly points out: 'protected areas cannot, and should not, be made or managed in isolation from the communities around them' ${ }^{21}$

One of international environmental law's strongest mechanisms to achieve this is the principle of public participation. Since its formulation in the Rio Declaration of $1992^{22}$ (Principle 10) public participation has become an integral component of how environmental law should work. In the context of protected areas, with which this paper is concerned, public participation was once a 'subsidiary issue' but has now moved to 'the centre stage'. ${ }^{23}$ Whilst there have been several studies that have looked at the Ramsar Convention in Japan, ${ }^{24}$ there have been relatively few which have evaluated the legal aspects of the principle as it applies (or ought to apply) under Ramsar. ${ }^{25}$ A large part of this is because conservation science has tended to use the broader phrase 'participatory management'. ${ }^{26}$ International law scholars, on the other hand, have confined participation largely to involvement in decision-making

17. Simba Chan, 'The North East Asian Crane Site Network' in G Boere, C Galbraith and D Stroud (eds), Waterbirds around the world: A global overview of the conservation, management and research of the world's waterbird flyways (The Stationary Office, Edinburgh 2006). 18. 'China Considers Red-crowned Crane for National Bird', China.org, (20 April 2007). $<$ http://www.china.org.cn/english/environment/208073.htm>.

19. Kim Malborg, Korean Dance (Ewha Womans University Press, Seoul 2005) 65.

20. Ben Boer and Stefan Gruber, 'Heritage Discourses' in K Rubenstein and B Jessup (eds), Environmental Discourses in International and Public Law (Cambridge University Press, Cambridge 2012).

21. Alexander Gillespie, Protected Areas and International Environmental Law (Martinus Nijhoff Publishers, Leiden 2007) 306.

22. Rio Declaration on Environment and Development, 2 UN Doc A/CONF.151/5/Rev.1 (1992) ('Rio Declaration').

23. Gillespie (n 21) 306.

24. See for example, Stephen Fletcher, Midori Kawabe and Sonja Rewhorn, 'Wetland conservation and sustainable coastal governance in Japan and England' (2011) 62(5) Marine Pollution Bulletin 956.

25. One exception to this is: Volker Mauerhofer, Rakhyun E Kim and Casey Stevens, 'When implementation works: a comparison of Ramsar Convention implementation in different continents' (2015) 51 Environmental Science \& Policy 95.

26. See for instance, Meg Gawler (ed), Strategies for wise use of Wetlands: Best Practices in Participatory Management: Proceedings of a Workshop held at the 2nd International Conference on Wetlands and Development (November 1998, Dakar, Senegal) (Wetlands International 
processes from government bodies (i.e. consultation). ${ }^{27}$ There is virtue in both approaches. Indeed, there is no reason why the two notions cannot be aligned with one another. That is to say, the legal principle of public participation can and should be nudged to encompass new meanings.

\section{METHOD AND APPROACH}

The increase in international environmental initiatives over the last five decades has not stayed the onslaught of pollution, dangerous climate change, biodiversity loss and land and marine degradation. Whilst there have been some reported successes, ${ }^{28}$ on the whole, we have failed to effectively value nature, including its biodiversity, its habitats, and the cultures that sustain them. ${ }^{29}$ In recent years, therefore, there has been a noticeable shift from the creation and establishment of multilateral environmental agreements (MEAs) towards questions of compliance, effectiveness and implementation. ${ }^{30}$ In the context of Ramsar, recent studies have focused on the implementation of the Convention's obligations in selected member states such as South Korea, Mexico, England and Japan. ${ }^{31}$ Lewis' paper on Ramsar and the operation of 'flyways' is also of note, in particular, her final argument that 'it is possible for parties to be in full compliance with their Ramsar commitments without adequately providing for the ecological needs of [migratory waterbirds]' ${ }^{32}$ The present paper adjoins these studies by examining, from a socio-legal perspective, the implementation of the principle of public participation and the role for communities under the Ramsar Convention.

New methods and frameworks to evaluate the effectiveness of environmental governance have recently found favour amongst legal scholars. ${ }^{33}$ As Martin and Kennedy suggest, we need to get better at empirically examining how and why our efforts to

IUCN, WWF Publication No. 56, Wageningen, The Netherlands) and Najmeh Daryaei et al, 'Designing pattern of participatory management in social sustainability of Fereydoon Kenar's wetland (Ramsar Site), Iran' (2015) 3(3) SAUSSUREA 279.

27. See for instance: Benjamin Richardson and Jona Razzaque, 'Public participation in environmental decision-making' (2006) Environmental law for Sustainability 165, and also Nicholas de Sadeleer, 'Tensions in Decision-Making Process Relating to the Environment: The Role of Public Participation' in Daniella Obradovic and Nikos Lavranos (eds), Interface between EU Law and National Law (Europa Law Publishing, Groningen 2007) 79.

28. For example The Montreal Protocol on Substances that Deplete the Ozone Layer 1522 UNTS 3; 26 ILM 1550 (1987) is often hailed as a successful MEA, largely because of its compliance regime. See Ian Rae, 'Saving the ozone layer: why the Montreal Protocol worked' The Conversation (online) September 10, $2012<\mathrm{https} / / / \mathrm{www}$.theconversation.com/saving-theozone-layer-why-the-montreal-protocol-worked-9249>.

29. See generally, Joshua Bishop and Chloe Hill (eds), Global Biodiversity Finance: The Case for International Payments for Ecosystem Services (Edward Elgar, Cheltenham 2014) 208.

30. Ronald Mitchell, Compliance Theory: Compliance, Effectiveness and Behavior Change in International Environmental Law (Oxford University Press, Oxford 2007).

31. See for example Fletcher et al (n 24).

32. Melissa Lewis, 'Migratory waterbird conservation at the flyway level: distilling the added value of AEWA in relation to the Ramsar Convention' (2016) 34(1) Pace Environmental Law Review 1.

33. Paul Martin, Ben Boer and Lydia Slobodian (eds), Framework for Assessing and Improving Law for Sustainability (IUCN, Gland, Switzerland 2016). 
formulate rules for environmental protection are not delivering the outcomes they have promised. ${ }^{34}$ This is also recognition that 'state made law' is only a small part of what makes up environmental governance. States are quickly becoming residual forces in conservation. Indeed, environmental governance is now a space inhabited by a wide variety of actors, including states, non-governmental organisations (NGOs), local communities, businesses, the media, scientific institutions, Indigenous Peoples and others. As Mitchell reminds us, it is the observed behaviors of these actors which matters, not simply the laws and rules that are intended to govern them. ${ }^{35}$

With this in mind, a socio-legal approach has been adopted in this paper which sought to take account not only of legal rules, but of an actor's 'social behavior' as well. The method drew on a recent test approach developed by scholars associated with the International Union for the Conservation of Nature (IUCN) which involved distinct stages of analysis. ${ }^{36}$ The first stage (1) involved something of a "positive analysis' ${ }^{37}$ of the principle of public participation as it currently exists under the Ramsar Convention, including reading widely in the social sciences, planning and conservation sciences literature. The purpose of this stage was to distill what the principle is, and how it had been adopted within the Ramsar framework. The second stage (2) involved an analysis of the extent to which domestic systems of environmental governance had adopted the principle into wetland and birdlife management; including by reference to laws, policies, strategies and other formal documents. The purpose of the second stage was to trace the existence of the principle from the international level to the domestic context. Finally, the third stage (3) involved a focus on the behavior of various actors that participate in wetland and birdlife protection. The second and third stages were applied to a desktop study of Japan's red-crowned crane population in the Ramsar Wetland areas of Eastern Hokkaido.

\section{RAMSAR AND THE PRINCIPLE OF PUBLIC PARTICIPATION}

\subsection{The Ramsar Convention}

Ramsar has been described as one of the 'big three' conservation treaties (the others being the World Heritage Convention and the CBD). ${ }^{38}$ More recently, it has been referred to as 'one of six' major biodiversity-related treaties. ${ }^{39}$ However it is categorized, it is clear that Ramsar now 'forms a core part of the international biodiversity governance system. ${ }^{40}$ The text of the Convention, which, as Redgwell says, is

34. Paul Martin and Amanda Kennedy (eds), Implementing Environmental Law (The IUCN Academy of Environmental Law series, Cheltenham, UK, 2015).

35. Mitchell (n 30).

36. Note in the pilot IUCN method, there are actually four stages of analysis, the final one being 'evidence of outcomes of implementation', but such a step was beyond the confines of this desktop analysis.

37. See Posner's explanation in Richard Posner, 'The present situation in legal scholarship' (1980) 90 Yale Law Journal 1113.

38. Jim Thorsell, 'Nature's Hall of Fame: IUCN and the World Heritage Convention' in Nordic World Heritage Office Oslo, Seminarraport: Verdensarv I Norden (Nordisk Ministerrad, Kobenhavn 1997) 33.

39. Mauerhofer et al (n 25) 96.

40. Ibid. 
'extraordinarily brief', ${ }^{41}$ operates by creating a framework for the conservation and protection of Wetlands of International Importance (i.e. 'Ramsar Sites'). At the time of writing, Ramsar had 169 contracting states (including Japan, China and South Korea) and a total of 2,293 Ramsar Sites. ${ }^{42}$ The 'primary conservation tool' of the Convention ${ }^{43}$ is found in article 2.1: 'each contracting party shall designate suitable wetlands within its territory for inclusion in a List of Wetlands of International Importance'.

Since its creation, Ramsar has had a strong focus on the protection of birdlife that uses and relies on wetlands for habitat. ${ }^{44}$ Indeed, the original title of the Convention was the 'Convention on Wetlands of International Importance especially as Waterfowl Habitat'. ${ }^{45}$ Since the 1990s, however, a noticeable shift 'from simple wetland management for waterfowl' towards a more integrated water management regime has occurred, including achieving a better understanding of the "cultural value of wetlands' ${ }^{46}$ This has been labelled as the trend from 'wetlands for birds' towards 'water for people'. ${ }^{47}$ The move appears to mirror a rise in the vernacular of 'sustainable development' and the recognition that many human communities value and rely on nature for a variety of spiritual, recreational and subsistence pursuits.

Today, the Ramsar Convention continues strongly to promote what is known as the 'wise use of wetlands', a definition of which was adopted at the third Conference of the Parties in 1987 (COP3): '[t]he wise use of wetlands is their sustainable utilization for the benefit of humankind in a way compatible with the maintenance of the natural properties of the ecosystem'. ${ }^{48}$

In 1990, at the fourth Conference of the Parties (COP4), guidelines were adopted for the implementation of the wise use concept. ${ }^{49}$ More recently the concept has been supported by the publication of a series of handbooks. The Convention now defines wise use of wetlands as: 'the maintenance of their ecological character, achieved through the implementation of ecosystem approaches, within the context of sustainable development' ${ }^{50}$ Finally, it should be noted that the wise use concept is applicable to all wetlands, not simply listed sites under the Convention.

41. Catherine Redgwell, 'The International Law of Public Participation: Protected Areas, Endangered Species, and Biological Diversity' in Donald Zillman, Alastair Lucas, and George (Rock) Pring (eds), Human Rights in Natural Resource Development: Public Participation in the Sustainable Development of Mining and Energy Resources (Oxford University Press, Oxford 2002) 202.

42. The Ramsar Convention Secretariat, 'About Ramsar' <https://www.ramsar.org/>.

43. Mauerhofer et al (n 25) 96.

44. For further on this point, see Lewis (n 32).

45. Technically, this is still the formal title of Ramsar, however it is no longer used in practice.

46. Robert Blasiak and Peter Bridgewater, 'Ramsar Convention at 41: New Dimensions' (United Nations University, May, 2015) <http://www.unu.edu/publications/articles/ramsarconvention-at-41-new-dimensions.html>.

47. Ibid.

48. Geoffrey Matthews, The Ramsar Convention on Wetlands: its History and Development (Ramsar Convention Bureau, Gland, Switzerland, 1993, reissued 2013) 48.

49. The Ramsar Convention on Wetlands, 'Recommendation 4.10: Guidelines for the implementation of the wise use concept', 4th Meeting of the Conference of the Contracting Parties Montreux, Switzerland, 27 June-4 July 1990.

50. Ramsar Convention Bureau, Handbook 1: Wise Use of Wetlands (Ramsar Convention Secretariat, 2010) 16. 


\subsection{Japan and Ramsar}

Japan is a collection of several thousand islands; about 500 of which are inhabited. Like other densely populated nations, Japan relies heavily on the availability and health of aquatic ecosystems (rivers, lakes, tidal flats, rice paddies, etc) ${ }^{51}$ In the last 150 years, however, the total size of Japan's wetlands (known as shitsugen) have decreased by close to 60 per cent. ${ }^{52}$ The loss of wetlands in Japan is part of a trend that appears consistent throughout much of East Asia, particularly China. The loss of tidal wetlands, for instance, in the Yellow Sea has been especially rapid with close to two-thirds being lost over the past five decades. ${ }^{53}$ Most of this seems to have been caused by the practices of landfill and land reclamation. ${ }^{54}$ Furthermore, as Haidary and others have shown, degradation of landscapes within wetlands themselves has caused serious 'deterioration of water quality'. 55

Despite the declines, or perhaps because of them, both state and non-state actors in Japan have had a strong history of engagement with restoration of aquatic systems. ${ }^{56}$ Since the 1980s, the Japanese Government has increasingly embraced the framework for wetland governance provided under the Ramsar Convention. Japan's alignment with Ramsar extends not only to their own sites, but also to financial and other contributions in projects around Asia. This has principally occurred through the 'Asia-Pacific Migratory Waterbird Conservation Strategy' ${ }^{57}$ and the work of Japan's International Cooperation Agency (JICA). ${ }^{58}$ As pointed out in Part 4 of the present paper, several NGOs (both wetland and birdlife-focused) have also been prominent players in the take-up of Ramsar across Japan.

Ramsar entered into force in Japan on 17 October 1980 and the nation currently lays claim to 50 Ramsar sites (with the four most recent being added in 2015). ${ }^{59}$ Japan has a list of '500 important wetlands' and is aiming for a goal of 100 Ramsar Sites to be listed by the time of the sixteenth meeting of the parties (COP16) in 2026. ${ }^{60}$ Most

51. Azam Haidary, Bahman Jabbarian, Amiri, Jan Adamowski, Nicola Fohrer and Kaneyuki Nakane 'Assessing the impacts of four land use types on the water quality of wetlands in Japan' (2013) 27(7) Water Resources Management 2217.

52. Keigo Nakamura, Klement Tockner and Kunihiko Amano, 'River and wetland restoration: lessons from Japan' (2006) 56(5) BioScience 419.

53. Nicholas Murray, Robert Clemens, Stuart Phinn, Hugh Possingham and Richard Fuller, 'Tracking the rapid loss of tidal wetlands in the Yellow Sea' (2014) 12(5) Frontiers in Ecology and the Environment 267-72.

54. Japan NGO Network for Ramsar COP10, 'For the Protection of Wetland Biodiversity An Examination of Wetland Policy in Japan', Ramsar COP10 Japan Information Packet (20 October 2008) 3.

55. Haidary et al (n 51).

56. Nakamura et al (n 52).

57. There have been two versions of the strategy where governments (such as Japan and Australia) have worked together to preserve waterbird habitat. See the Asia-Pacific Migratory Waterbird Conservation Strategy: 1996-2000 (Wetlands International - Asia Pacific, 1996); and Asia-Pacific Migratory Waterbird Conservation Strategy: 2001-2005 (Wetlands International - Asia Pacific, 2001).

58. Ramsar, National Planning Tool for the Implementation of the Ramsar Convention on Wetlands (And the approved format for National Reports to be submitted for the 9th Meeting of the Conference of the Contracting Parties, Uganda, 2005).

59. Ramsar News, 'Four new Ramsar Sites for Japan' (30 November 2015) <http://www. ramsar.org/news/four-new-ramsar-sites-for-japan>.

60. Japan Wetlands Action Network (JAWAN) 'Present status of Japan's wetlands' < http:// www.jawan.jp/e/jawan/present_status.html>. 
of Japan's sites are freshwater bodies including lakes and ponds. ${ }^{61}$ The first site to be declared in Japan was the Kushiro-shitsugen ('Kushiro wetland') on the Eastern part of Japan's North Island of Hokkaido. Hokkaido has had a strong focus with Ramsar and wetland conservation. In 1993, the city of Kushiro, for instance, hosted the fifth Conference of the Parties to Ramsar (COP5) which raised 'awareness of the objectives of the Ramsar Convention in Japan and the rest of Asia' ${ }^{62}$

In terms of legislation, Japan has several domestic laws which directly or indirectly relate to the protection of its Ramsar sites. ${ }^{63}$ These include: the Basic Environmental Law (1993); the Law on Conservation of Endangered Species of Wild Fauna and Flora (1993); the Nature Conservation Law (1972); the Invasive Alien Species Law (2004); the Natural Parks Law (1957); and the Wildlife Protection and Appropriate Hunting Law (2002). In 2002, the Law for the Promotion of Nature Restoration was enacted 'to promote nature restoration through bottom-up approach and facilitating consensus among various local actors'. ${ }^{64}$ Japan also has an Environmental Impact Assessment Law (EIA Law), although some have argued that this is incapable of requiring the effective consideration of alternatives to development affecting wetlands. ${ }^{65}$ For instance, whilst 'biodiversity' is one of the factors that needs to be considered under the EIA Law, not every project that has impact on wetlands will automatically require impact assessment. It has been reported that most projects which affect Japan's wetlands are 'left to local ordinances and guidelines" ${ }^{66}$ which may or may not take account of the Ramsar framework. For those projects that do require EIAs, 'the specifications for the project ... have [usually already] been completely determined' by the relevant authorities. ${ }^{67}$

Japan's national government is supplemented by 47 smaller prefectures. The island of Hokkaido is one of those prefectures. Prefectures are further divided into smaller localities known as sub-prefectures (shichō) comprised of smaller cities and villages. For instance, the Kushiro sub-prefecture (Kushiro-sōgō-shinkō-kyoku) includes the towns of Akkeshi and Akan and is home to the Kushiro Ramsar site which forms part of the case study below. There are currently over 80 'relevant municipalities' across Japan that work with local residents, industry, NGOs and the national government to 'promote wetland conservation'. ${ }^{68}$ To coordinate the role of the different municipalities, a 'Domestic Ramsar Committee for Relevant Municipalities' (RCM) has been established. The objective of the RCM is to promote regional wetland conservation activities amongst the relevant municipalities. ${ }^{69}$ As at August 2016, the RCM had 68 municipal members. The RCM organizes education and training programs, conducts sharing of

61. Japan NGO Network for Ramsar COP10 (n 54).

62. Ministry of the Environment Government of Japan, 'Ramsar Sites in Japan' <http://www. env.go.jp/en/nature/npr/ramsar_wetland/pamph/>.

63. For a summary, see John Ramsay Mackinnon and Xie Yan, Regional action plan for the protected areas of East Asia 2006-2010 (Korean version) (IUCN, Gland 2008) 20.

64. Ramsar (n 58).

65. Japan NGO Network for Ramsar COP10 (n 54) 4.

66. Hidefumi Imura and Miranda Schreurs (eds), Environmental Policy in Japan (Edward Elgar, Cheltenham 2005) 212.

67. Ibid, 212.

68. Wetlands International <http://www.japan.wetlands.org/>.

69. Domestic Ramsar Committee for Relevant Municipalities' (RCM) <http://www.ramsarsite.jp/index.html>. 
information and other collaborations at both the sub-prefectural and national level. ${ }^{70}$ Tanaka has recently studied the Man-ko wetland Ramsar site (in Okinawa). ${ }^{71}$ His work, which was empirical in approach, concluded that the RCM was one of the key institutions in the implementation of Ramsar in Japan. ${ }^{72}$

\subsection{Public participation under Ramsar}

The legal principle of 'public participation' is most clearly enunciated in the Rio Declaration 1992, 'Principle 10' of which states: '[e]nvironmental issues are best handled with the participation of all concerned citizens, at the relevant level ... and each individual shall have ... the opportunity to participate in decision-making processes.'

Ramsar was established some two decades before Rio and it is understandable there is no specific mention of the principle in the original text. That is not to say that such a role for civil society was unheard of at the time. The text of the World Heritage Convention, ${ }^{73}$ for instance, adopted in 1972, required 'cooperation' with NGOs having objectives similar to those of the Convention. ${ }^{74}$ Perhaps the closest Ramsar came to this was article 7 which allowed for conferences to 'include persons who are experts on wetlands or waterfowl by reason of knowledge and experience gained in scientific, administrative or other appropriate capacities'. That said, article 7 stopped short of more strategic involvement for NGOs in the implementation of the Convention. This is despite the fact that NGOs were prominent forces in the creation of the treaty from the outset.

Nevertheless, over the last four decades contracting states and the Ramsar Secretariat have increasingly highlighted the relevance of community involvement in wetland management. In particular they have sought to promote the role of Indigenous People in managing and protecting Ramsar sites. A large part of this can be traced to Ramsar's Leiden Conference in the Netherlands in 1989 which focused on 'the People's Role in Wetland Management' ${ }^{75}$ As Matthews recounts in his history of the Convention, the Leiden Conference sought out new ways in which 'local people could be 'integrated' under Ramsar. ${ }^{76}$ In addition, as noted above, the early 1990s was also the point at which Ramsar began to shy away from protection for waterbirds and towards conserving wetlands for people-recognizing and encouraging their wise use.

The formation of a more concrete plan for community involvement in wetland conservation came in 1993, in Kushiro, Japan (COP5), where a working group recommended that States: "establish procedures which guarantee that local communities are involved in the decision-making process related to wetland use, and provide

70. Domestic Ramsar Committee for Relevant Municipalities' (RCM) <http://www.ramsarsite. jp/ramsarkaigi.html>.

71. Toshinori Tanaka, 'The structure of decision-making and information sharing in the national implementation of the Ramsar Convention: public-private collaborative networks and local institutions' (2016) 42(1) People and Environment 2.

72. Ibid.

73. Convention for the Protection of the World Cultural and Natural Heritage 1037 UNTS

151; 27 UST 37; 11 ILM 1358 (1972).

74. Ibid, Art 13(7).

75. Matthews (n 48) 48.

76. Ibid, 54. 
local communities with sufficient knowledge of planned activities to ensure their meaningful participation in this decision-making process. ${ }^{77}$

Three years later, in 1996 (COP6 in Brisbane), further recommendations were made which called upon contracting parties to 'make specific efforts to encourage active and informed participation of local and indigenous people at Ramsar-listed sites' ${ }^{78}$ In 1999 , a set of guidelines were produced for 'establishing and strengthening local communities' and indigenous people's participation in the management of wetlands' 79 (the Participation Guidelines). Relevantly for the purposes of this paper, Japanese organizations such as the Kushiro International Wetlands Centre, the Aeon Foundation, the Ramsar Centre and WWF-Japan played an instrumental role in the development of the guidelines. ${ }^{80}$

As Lausche and Burhenne-Guilmin point out, the Participation Guidelines encouraged not only involvement in government decision-making, but also 'the assumption of responsibility, by local communities and indigenous peoples in the management of Ramsar-listed sites and other wetlands, and in the implementation of the wise use principles at the local level. ${ }^{81}$

The 'assumption of responsibility' provided a key recognition, not just of existing usage rights that might exist at Ramsar sites, but also a more transformative vision whereby communities could be empowered and legitimized to assume a degree of control. Although the Participation Guidelines have not been updated since 1999, they were included as an annexure in the Ramsar Handbook on participatory approaches to wetland management released by the Secretariat in $2010{ }^{82}$ The seventh handbook of that series (titled 'participatory skills') provides information on why community involvement is beneficial; lessons learned from community involvement; knowledge exchange and capacity building; engaging local and indigenous people; and monitoring and evaluating the involvement of local people in wetland management.

All of this suggests, as Redgwell points out, that a participatory role for non-state actors in Ramsar Wetland management has experienced 'significant growth' over the last 30 years. ${ }^{83}$ It seems clear that, since about 1989, various strategies, objectives and resolutions have supported a place for 'major groups' (i.e. NGOs), local communities, Indigenous Peoples and the private sector to take part, not only in the Ramsar identification and listing process, but also the 'management, restoration and rehabilitation' of sites. ${ }^{84}$ The 2008 Changwon Declaration foresaw an integral role for communities in wetland 'stewardship' noting that 'sustainable wetland management should be supported by indigenous and traditional knowledge, recognition of cultural identities associated with wetlands, stewardship promoted by economic incentives, and diversification of the support base for livelihoods'. ${ }^{85}$ More recently, the 2010 handbook

77. Ramsar Convention Bureau, Handbook 7 Participatory Skills (Ramsar Convention Secretariat, Gland 2010) 28.

78. Ramsar Convention Bureau, Establishing and strengthening local communities' and indigenous peoples participation in the management of wetlands (Ramsar Convention Secretariat, Gland 2000) 4.

79. Ibid.

80. Ibid, 2.

81. Barbara Lausche, Guidelines for Protected Areas Legislation (IUCN, Gland 2011) 94.

82. Redgwell (n 41) 204.

83. Ibid, 202.

84. Ibid, 203.

85. Ramsar Convention Bureau, Changwon Declaration on human well-being and wetlands, Resolution X.3 adopted Changwon, Republic of Korea, 28 October-4 November 2008, 5. 
makes it abundantly clear by referring very specifically to a role for stakeholders in 'resource management' which is said to fall 'within the general resource management approach known as participatory management'. ${ }^{86}$

It is worth pausing here to make two points. The first is that participatory approaches to environmental governance were still being tried and tested at the time the Participation Guidelines were introduced (1999). Consider, for instance, these cautionary words from the Ramsar Secretariat at the time:

[r]eaders should be aware that new experiences in participatory wetland management are being documented regularly. The wealth of material, together with the breadth of participatory management experiences, makes it impossible to provide a definitive text on this subject. Rather, this should be seen as a work in progress. ${ }^{87}$

1998 was also the occasion that the Aarhus Convention ${ }^{88}$ was adopted (by the European Community, although it is now open for universal signature). Ramsar's Participation Guidelines thus represented a point in time at which concerns around the procedural rights of local communities and civil society more broadly had come to the fore on international agendas. As Lee and Abbot recall, by the time Aarhus was introduced, it was clear that 'a consensus on the importance of public involvement in environmental decision-making [had] been achieved. ${ }^{89}$ Thus Ramsar was not alone in its drive for increased community participation in conservation issues reflecting a broader movement which had begun at Rio several years prior.

The second and more interesting point to note, however, is that Ramsar has apparently preferred the language of 'participatory management' rather than of 'public participation'. The Convention goes on to suggest that terms such as 'collaborative, joint, community-based or co-management are more or less synonymous' with this concept. ${ }^{90}$ In any event, there are fine but important points of difference between public participation (in the legal principle sense) and participatory management (in the Ramsar sense) that ought to be reconciled.

Public participation in itself is a widely contested term. ${ }^{91}$ There exists in the literature a variety of meanings of the term, ${ }^{92}$ including discrepancies over whom it includes (i.e. who is 'the public'), whether or not it is an accepted 'rule', ${ }^{93}$ and the most effective way of ensuring that the public can truly participate in governance activities. ${ }^{94}$ Under the

86. Ramsar Convention Bureau (n 77) 6.

87. Ibid, 4.

88. Convention on Access to Information, Public Participation in Decision-Making and Access to Justice in Environmental Matters (Aarhus Convention) (1999) 2161 UNTS 447; 38 ILM 517.

89. Maria Lee and Carolyn Abbot, 'The usual suspects? Public participation under the Aarhus Convention' (2003) 66(1) The Modern Law Review 80.

90. Ramsar Convention Bureau (n 77) 6.

91. Judith Innes and David Booher, 'Reframing public participation: strategies for the 21st century' (2004) 5(4) Planning Theory and Practice.

92. See Roger Few, Katrina Brown and Emma L Tomkins, 'Public participation and climate change adaptation: avoiding the illusion of inclusion' (2007) 7(1) Climate Policy 46.

93. Melvin Woodhouse, 'Is public participation a rule of the law of international watercourses?' (2003) 43 Natural Resources Journal 137.

94. See Caron Chess and Kristen Purcell, 'Public participation and the environment: do we know what works?' (1999) 33(16) Environ. Sci. Technol 2685 and also Lucie Laurien, 'Public participation in environmental decision making: findings from communities facing toxic waste cleanup' (2004) 70(1) Journal of the American Planning Association 53. 
classic 'legal formulation' of the principle, found for instance in the Aarhus Convention, public participation is narrowly construed to refer to taking part in 'environmental decision-making' (i.e. a procedural right to consultation). Article 6 of Aarhus, for example, states that the public should be informed about decisions ahead of time, and should be allowed to partake in discussions or raise objections before any permits are issued. Moreover, article 6(8) of the Convention provides that the public should be allowed: 'to submit, in writing or, as appropriate, at a public hearing or inquiry with the applicant, any comments, information, analyses or opinions that it considers relevant to the proposed activity.'

Thus, in the Aarhus encapsulation of public participation, the public should be entitled to have 'a say' in decisions which affect their health, heritage and/or surrounding environment with the intention of influencing, or at least being able to influence, the outcome. In practice this might include, for example, commenting on environmental impact statements, responding to community consultations on strategic or other policy documents, engaging with parliamentary enquiries or new legislation; attending town hall meetings or community workshops. It is suggested in this article that this rather narrow view of participation - as essentially 'a right to consultation' flowed from the way the principle was promulgated under Rio several years earlier.

The present paper, however, adopts a broader and more expansive definition of public participation as also including 'hands on' community management of wetlands and their dependent birdlife. It does this not to disagree with established norms or discourses around what the legal principle of public participation has involved (it does seem the narrower construct reflects the development of the principle post-Rio); but, rather, to suggest that in the context of protected areas governance, the principle will have far more wide-reaching impact in terms of driving an agenda for 'real' community influence on conservation outcomes.

Accordingly, the analysis that follows sees public participation as any form of public involvement in environmental decision-making (proposed laws, policies, impact assessments etc) as well as other more 'hands on' activities the public might be involved with such as gathering technical information about bird life and wetland quality ('citizen science'), monitoring of corporate or state-party behavior, campaigning and lobbying for stronger protections, including for instance public education and training programs on wetland management. This conception aligns with that of the broader conception by Dietz and Stern. ${ }^{95}$

\section{CASE STUDY}

\subsection{The red-crowned crane (tancho)}

The tancho-zuru (tancho), also known as the Manchurian crane, the Japanese crane or the red-crowned crane is the largest of the world's 16 crane species. The tancho's wing span can measure up to two and a half meters and its $7.5 \mathrm{~kg}$ body (fully grown) is uniquely marked by a red patch on the top of its head. ${ }^{96}$ The red-crowned crane can live up to 25 years and is said to be loyal to its mate for life. Cao and others' study of the tancho noted: 'the red-crowned crane is a wetland specialist that prefers

95. See Thomas Dietz and Paul C Stern (eds), Public Participation in Environmental Assessment and Decision Making (National Research Council, Washington DC 2008) 1.

96. In the Japanese language 'tan' means 'red' and 'cho' means 'on top of the head'. 
reed marsh and intertidal mudflat habitats, both of which have low vegetation cover, shallow water, abundant food and low levels of human disturbance' ${ }^{97}$ There are two populations of the red-crowned crane, one 'permanent' population on the eastern side of Japan's Island of Hokkaido, and the other (a migrating population) in the northern parts of China and Korea and the south East of Russia. ${ }^{98}$ The Japanese population of the tancho lives predominately in Hokkaido's Eastern Ramsar Wetlands. It has been reported that there are no significant genetic differences between the two crane populations. ${ }^{99}$

The Japanese population of the red-crowned crane was hunted between the seventeenth century and the twentieth century (from the Edo period to the Meiji period). During this time there were 'no restrictions on hunting' and, eventually, 'over hunting caused many to believe that the red-crowned crane had become extinct'. ${ }^{100}$ When hunting of the crane was finally outlawed in Hokkaido, Japanese farms continued to 'swallow up' the wetlands where the tancho used to forage for insects and fish. ${ }^{101}$ Rather fortuitously, in the 1920 s a dozen cranes were discovered by a local Hokkaido community and carefully nursed back to health. ${ }^{102}$ Their numbers grew steadily and, by the 1950s, a local farmer, Sadajiro Yamazaki, had begun successfully feeding the cranes on a routine basis. Despite their numbers rising to around 1,000 in Hokkaido, the red-crowned crane is still listed as 'endangered' on the IUCN's red list. ${ }^{103}$ Its endangered status is caused by declines in continental Asian populations principally caused by degradation of wetlands through agriculture and industrial development. ${ }^{104}$

\subsection{Cultural significance of the tancho}

Crane species have long held mythological relevance in many regions of the world, including the Aegean, South Arabia, China, Korea, Japan and North America. ${ }^{105}$ The red-crowned crane has a sacred place in the hearts of many Japanese. It is designated as 'a Special Natural Monument of Japan' and, according to legend, it is said to

97. Mingchang Cao, Haigen Xu,Zhifang Le, Mingchang Zhu and Yun Cao, 'A multi-scale approach to investigating the red-crowned crane-habitat relationship in the Yellow River Delta Nature Reserve, China: implications for conservation' (2015) 10(6) PLoS ONE.

98. Ibid.

99. Meine and Archibold (n 9) 195.

100. 'Steward of Kushiro Marsh - The Japanese Red-crowned Crane Part 2' <http://www. kamkankouken.jp/tourism/en/kushiro/special/57.html>.

101. National Geographic, 'Japan's Dancing Cranes' <http://www.nationalgeographic.org/ video/japans-dancing-cranes/ $>$ at 1 minute 50 seconds.

102. Ibid, 3 minutes 05 seconds.

103. The most recent published assessment from the IUCN about the tancho was released in 2013. See IUCN, 'Red List of Threatened Species: Grus japonensis' <http://www.iucnredlist.org/ details/22692167/0>.

104. BirdLife International (2017) Species factsheet: Grus japonensis. Available online at $<$ http://www.birdlife.org $>$. See also IUCN (ibid) for further information on habitat and ecology, conservation actions and major threats. The key threat is reported on the IUCN's Red List to be 'the loss and degradation of wetlands in its breeding and wintering grounds, principally for conversion to agriculture, but also aquaculture and industrial and economic development'.

105. Yury Lobo, In the Wake of Basho: Bestiary in the Rock Garden (Xlibris, Bloomington 2016). Note, the Kindle edition of this book the author purchased has no page numbers. Refer from 'Rock 13' onwards in this collection. 
live for 1,000 years. It is the symbol of Japan's national carrier-Japan Airlines(although this was first suggested by an American brand strategist!) ${ }^{106}$ and is portrayed in artistic works such as Utagawa Hiroshige's 'One Hundred Famous Views of Edo' and the emotional practice of healing known as Senbazuru (making 1,000 paper cranes). It is also depicted on bridal kimonos in Japan, ${ }^{107}$ and was used in the design of Japan's 1,000 yen note. ${ }^{108}$ To the Ainu people of Japan, Hokkaido's indigenous inhabitants who lived on the island long before Japanese settlers arrived, the tancho is known as the Sarurun Kamuy or 'God of the Marshes'. The Ainus practise a crane dance (known as Sarorunrimuse) which portrays the elegant movements of the crane in its natural habitat. ${ }^{109}$

In neighboring China there have long been important Taoist philosophic connects to cranes. ${ }^{110}$ There are cranes located in the buildings of Beijing's Forbidden City (constructed from 1406 to 1420), which symbolize 'perpetuity or longevity'. ${ }^{111}$ The tancho was also recently a contender for national bird of China, but, as Lobo reports, the decision was 'deferred' because of the connection with the Japanese species. ${ }^{112}$ The Yiho-ming site ('rock inscription of a dead crane') dates back to the sixth century and is described as 'one of the hallowed monuments of Chinese culture'. ${ }^{113}$ The inscription 'was a dedication by an ancient Chinese calligrapher to a dead crane he [had] raised'. ${ }^{114}$

In Korea, the red-crowned crane (known as the durumi) also has special cultural significance, appearing in 'paintings, tapestry, and other decorative arts'. ${ }^{115}$ Like the Ainu (above), the Koreans have durumi-inspired dances dating back to the seventh century which were originally performed for Korean royalty (Silla Dynasty, 57 BC-935 AD). ${ }^{116}$ Today, the durumi winters each year in the Cheorwon Basin near Korea's demilitarized zone (DMZ) which separates war-torn North and South Korea. Fortuitously, the DMZ 'has become something of an unintended nature reserve' as the durumi is shielded from the relentless noise and human development in other parts of East Asia. ${ }^{117}$ A recent report from Birds Korea noted that 'as a result of artificial feeding programs and lack of persecution', Cheorwon now supports an increasing number of durumi. ${ }^{118}$

106. Ibid.

107. Meine and Archibold (n 9) 13.

108. Lobo (n 105).

109. Eriko Aoyagi, 'Girl embraces Ainu dance, shivers her timbers', The Japan Times (21 February 2014) <http://www.japantimes.co.jp/news/2014/02/21/national/girl-embraces-ainudance-shivers-her-timbers/>.

110. Marilyn Wong-Fu, 'The Impact of the Re-unification: Northern Elements in the Life and Art of Hsien-yu Shu (1257-1302) and Their Relation to Early Yuan Literati Culture' in JD Langlois Jr (ed), China Under Mongol Rule (Princeton University Press, Princeton 2014) 425.

111. Geremie Barmé, The Forbidden City (Harvard University Press, Cambridge MA 2008) 32.

112. Lobo (n 105).

113. Richard M Barnhart, Peach Blossom Spring: Gardens and Flowers in Chinese Paintings (Yale University Press, London 2013) 49.

114. 'Giant stones may be remnants of ancient cliff inscription', China.org (29 June 2010) $<$ http://www.china.org.cn/china/2010-06/29/content_20381111.htm>.

115. Meine and Archibold (n 9) 13.

116. Lobo (n 105).

117. Eric Wagner, 'The DMZ's Thriving Resident: The Crane', Smithsonian Magazine (April 2011) <https://www.smithsonianmag.com/science-nature/the-dmzs-thriving-resident-the-crane953694/>.

118. Nial Moores, Andreas Kim and R Kim, Status of Birds, 2014: Bird Population Trends and Conservation Status in the Republic of Korea (Birds Korea, Namcheong-Dong 2014) 7. 
There are very real cultural and political ramifications in all of this. Recent work from the Korea Society, for instance, has revealed the significance of the crane to Korean culture and suggests that it could represent a model for peace efforts between North and South Korea which have endured a tense relationship since the 1950s. ${ }^{119}$ The society noted that the durumi was 'a prime example of an animal taking on great importance socially, economically, and politically in Korean culture' ${ }^{120}$ It is a culture that both North and South Koreans have for centuries shared. Likewise, the crane's migratory habits across China, Russia and Mongolia could be (and have been) the source of positive transnational cooperation between scientific and conservation communities. ${ }^{121}$ In short, the loss of the red-crowned crane would likely have profound cultural impacts on countries across East Asia; but, equally, collaborations to preserve the species could provide fertile ground for improving strained diplomatic relations (e.g. between North and South Korea; and between China and Japan).

\subsection{Tancho habitat and Hokkaido's eastern wetlands}

Japan's north island of Hokkaido is home to 13 Ramsar sites-over one-fifth of Japan's total listed sites. The Kushiro wetlands, the largest (and first) Ramsar wetland site in Japan, are a primary breeding ground for the tancho though they are also reported in neighboring wetlands of Furen-ko and Shunkuni-tai as well. Kushiro was first declared a national natural monument in Japan in 1935 and in 1958 the area was declared a 'wildlife protection area'. In 1980 it was Japan's first registered Ramsar site and in 1987 was declared a national park. A Wetland Restoration Committee has been established which works with the local communities to maintain and improve the site. ${ }^{122}$

In May 1993, the Japanese Government established the Kushiro Wildlife Center which conducts surveys and research on the ecosystem of the wetlands, including the tancho, and provides educational activities on the conservation of biodiversity in the wetlands. The Tsurui-Ito Red-crowned Crane Sanctuary, just north of Kushiro, is one of the most well-known red-crowned crane feeding sites in Hokkaido. It is home to about 300 tancho and draws thousands of tourists every year. The Tsurui site was originally established in 1987 by the Wild Bird Society of Japan (WBSJ) following a recommendation from a special committee comprised of "nature conservation groups and ornithologists'. ${ }^{123}$ It was named after Yoshitaka Ito "who spent many years helping to feed the red-crowned crane while operating his own dairy farm' ${ }^{124}$

119. Edwin Pierce, 'Korea and the Red Crowned Crane: How the Natural World is Reflected in Korean Culture and a possible model for reunification: A lesson plan' (unpublished) available at <http://www.koreasociety.org/doc_view/885-korea-and-the-red-crowned-crane-how-the-naturalworld-is-reflected-in-korean-culture-and-a-possible-model-for-reunification-by-pierce-edwin $>$. 120. Ibid, 1.

121. International Crane Foundation Species Field Guide, 'Red-crowned Crane', <https:// www.savingcranes.org/species-field-guide/red-crowned-crane/>.

122. Kushiro Nature Conservation Office, Ministry of the Environment, 'Kushiro Shitsugen National Park', <http://www.inbound-jp.info/wp-content/pdf/kushiroshitsugen_brochure_en. pdf $>$.

123. Website of the Wild Bird Society of Japan, <https://www.wbsj.org/en/tsurui/>.

124. 'Steward of Kushiro Marsh - The Japanese Red-crowned Crane Part 3' <http://www.kamkankouken.jp/tourism/en/kushiro/special/66.html>. 
The WBSJ continues to carry out 'maintenance works' at Tsurui including, for instance, 'creating shores and cutting down overgrown trees' as well as feeding the cranes on a regular basis. ${ }^{125}$ They also produce educational guides and hold lectures about the crane and its habitat. ${ }^{126}$ In 1996, the site was declared one of the top 100 soundscapes in Japan, following a project by the Japanese Environmental Protected Agency, in an effort to 'preserve the natural and cultural heritages all around the country based on the concept of soundscape'. ${ }^{127}$ In addition to the Kushiro Wetlands, the tancho breeds at the Kiritappu-shitsugen Marsh, Lake Akkeshi and Bekambeushishitsugen (in Akkeshi town); ${ }^{128}$ and several birds have also been spotted at the Notsuke-hanto Peninsula (Notsuke Bay Area). ${ }^{129}$ Cranes are also fed at other locations in Hokkaido such as the Tsurumidai Feeding Point and the nearby Akan International Crane Centre.

\subsection{The relevance of state and non-state actors}

This next part of the paper provides a desktop evaluation on the implementation and utilization of the principle of public participation as it applies to the crane populations and wetlands habitats of Eastern Hokkaido. It discusses some of the behaviors of various state and non-state actors regarding the conservation of cranes and their wetlands and points out areas where instances appear to be working effectively and areas where it might be improved. In the end, the case study example reveals a model working reasonably well, with the exception of the Japanese Government's neglect of a prominent role for the Indigenous (Ainu) people and the fact that public participation in environmental impact assessment in Japan does not appear specifically to factor in Ramsar considerations (referring only to 'biodiversity'). The EIA process also seems to lack 'public communication' during the scoping stages of the project. ${ }^{130}$

Much of the good work undertaken by stakeholders seems to have pre-dated Ramsar and the rise of modern environmental governance. It thus cannot be said that any principle of participation (in the law) was the driver of activities in the area, nor for that matter the concept of 'participatory management' under Ramsar. Nevertheless, the Convention framework continues to provide a powerful blueprint for community participation, which would otherwise not exist today. It is difficult to conclude how much of that involvement is attributable to the principles of Ramsar and how much is down to the unique cultural relationship the Japanese people have with restoring and maintaining their environs. As renowned East Asian scholar and Japanologist Allan Grapard once wrote: "[i]t might be said that what has been termed "the Japanese love of nature"

125. Wild Bird Society of Japan (n 123).

126. Ibid.

127. Keiko Torigoe, 'Insights Taken from Three Visited Soundscapes in Japan' (University of the Sacred Heart, Working Paper).

128. Wetland Link International, 'Kushiro International Wetland Centre' <http://www.wli. wwt.org.uk/2012/11/members/asia/asia-members/kushiro-international-wetland-centre-2/ \#tab-1>.

129. Japan National Tourism Organization, 'Bountiful wetlands where wildlife flourishes' <http://www.jnto.go.jp/eng/indepth/scenic/hokkaido/hokkaido_02.html>.

130. Kiichiro Hayashi, 'How to Improve Japanese EIA legislation by Utilizing International Experience' ('IAIA08 Conference Proceedings', The Art and Science of Impact Assessment 28th Annual Conference of the International Association for Impact Assessment, 4-10 May 2008, Perth Convention Exhibition Centre, Perth, Australia) 3. 
is actually the "Japanese love of cultural transformations and purification of a world which, if left alone, simply decays".,131

To answer this, a far deeper understanding of the link between Japanese nature and culture is needed, with specific focus on wetlands and birdlife. Further research would therefore be beneficial, particularly of an empirical nature (interviews, documentary analysis, etc) to help understand how and why Japan's communities engage in wetland conservation in the ways they do.

\subsubsection{The role of government}

As Mauerhofer remarks, the Ramsar Convention gives governments 'significant leeway' over questions of implementation. ${ }^{132}$ Ferrajolo argues likewise, suggesting that obligations under Ramsar are very general in nature. ${ }^{133}$ Redgwell also agrees, and notes that, in the process of listing Ramsar sites, the extent of public participation can vary widely according to each country's national legislation. ${ }^{134}$ On the other hand, in the post-listing context (e.g. monitoring, education and restoration) comprehensive guidance is available, for instance in the form of the Ramsar Handbook (2010) and the Participation Guidelines (1999). These initiatives seem to reflect, as Gillespie notes, a 'thematic' approach to the application of the principle rather than on a site-by site basis. ${ }^{135}$ In any event, the role for governments like Japan should be to facilitate (or at least not obstruct) public involvement at the site level through a mixture of national, prefectural and local initiatives.

There is some evidence that the Japanese government has done this and indeed used the Convention framework (and possibly even the guidelines) as a way of persuading communities to become involved in birdlife and wetland conservation. A recent study, for instance, by Fletcher, Kawabe and Rewhorn found that Ramsar has been used in Japan as leverage to 'encourage citizen engagement, economic benefit, and wetland conservation at the local level'. ${ }^{136}$ It is the brand of Ramsar that has become key and has been used by the state to "encourage much greater levels of community and stakeholder engagement with environmental protection issues and to perceive positively the "value" of wetland sites'. ${ }^{137}$ The authors concluded that: 'Ramsar designation in Japan therefore appears to be used as a rationale for citizen engagement, a source of civic pride, community identity and economic well-being. ${ }^{\text {, }} 38$

Regulatory scholars might refer to the creation of these conditions as 'steering'. 139 In the 'nautical' analogy of 'steering and rowing', steering refers to mapping or

131. Allan Grapard, 'Nature and Culture in Japan' in Michael Tobias (ed), Deep Ecology (Avant Books, San Diego 1985) 247. For further reflections on Japan, nature and culture, see Pamela Asquith and Arne Kalland (eds), Japanese Images of Nature: Cultural Perspectives (Curzon Press, Surrey 1997).

132. Mauerhofer et al (n 26) 102.

133. Ornella Ferrajolo, 'State obligations and non-compliance in the Ramsar system' (2011) 14(3-4) Journal of International Wildlife Law \& Policy 243.

134. Redgwell (n 42) 202.

135. Gillespie (n 22) 182.

136. Fletcher et al (n 25) 956.

137. Ibid, 958.

138. Ibid, 960 .

139. David Osborne and Ted Gaebler, Reinventing Government (Addison-Wesley Publishing Company, Boston MA 1992). 
strategizing the course for future management, and where necessary, 'monitoring the direction and correcting [any] deviations from the course'. ${ }^{140}$ Steering allows the state to be a 'facilitator of self-and co-regulation rather than [managing the issue] directly'. ${ }^{141}$ The government's actions in installing civic pride and community spirit have obvious benefits in terms of saving public resources and tapping into the expertise available in epistemic, indigenous and local communities. It can also add a level of independence, trust and impartiality to wetland management processes under the framework.

Furthermore (and still on the analogy of steering) the Japanese government has developed and published a National Biodiversity Strategy (2012-2020) which includes a detailed 'Roadmap towards the Establishment of an Enriching Society in Harmony with Nature.' ${ }^{142}$ The national strategy foresees an increase in the size of Japan's Ramsar sites but cautions that such nominations should only occur after 'obtaining support and cooperation from local communities'. ${ }^{143}$ Other comments from the national government are also encouraging. Consider for instance, these words taken directly from the document:

[Japan's Government] will proceed with conducting monitoring surveys, organizing information and restoring wetlands on Ramsar Sites, in cooperation with relevant local governments, local residents, NGOs, experts and other parties including the [RCM] where municipalities with Ramsar Sites voluntarily participate. The [Japanese] government will also promote the conservation and wise use of Ramsar Sites by tapping into the local climate and culture of each Ramsar Site, by supporting the formulation of plans for the conservation and wise use of Ramsar Sites, providing information about successful cases of wise use and raising public awareness. ${ }^{144}$

There is also some evidence that the national government in Japan has been instrumental in working with and funding cooperative transnational initiatives such as the North East Asian Crane Site Network (NEACSN) in $1997^{145}$ which helped to facilitate the cooperation and exchange of information about the red-crowned crane. ${ }^{146}$ NEACSN had as its main goal the conservation of crane species 'and their habitats in north-east Asia' ${ }^{147}$ Three of Hokkaido's Ramsar sites became part of the Network:

140. Adam Crawford, 'Networked governance and the post-regulatory state? Steering, rowing and anchoring the provision of policing and security' (2006) 10(4) Theoretical Criminology 453. Rowing, by comparison, refers to the actual delivery (or 'implementation') of services. See Osborne and Gaebler, ibid, 25.

141. Neil Gunningham and Cameron Holley, 'Bringing the "R" Word Back: Regulation, environment protection and NRM' Occasional Paper 3/2010 The Academy of the Social Sciences in Australia Canberra, 11.

142. The National Biodiversity Strategy of Japan 2012-2020, Roadmap towards the Establishment of an Enriching Society in Harmony with Nature (28 September 2012).

143. Ibid, 142.

144. Ibid, 143 .

145. NEACSN was first established to act as one of several networks supporting the 'AsiaPacific Migratory Waterbird Conservation Strategy' (1996). See above (n 57). It was formally established under the East Asia-Australasian Flyway Partnership (EAAFP) which today 'provides a flyway wide framework to promote dialogue, cooperation and collaboration between a range of stakeholders to conserve migratory waterbirds and their habitats.' For more information, see East Asia-Australasian Flyway Partnership, 'The Partnership' < http://www.eaaflyway. net/about/the-partnership/>.

146. International Crane Foundation Species Field Guide (n 121).

147. Chan (n 17) 320. 
Kiritappu; Akkeshi-Bekanbeushi; and Kushiro. The Network-which has now become the 'Crane Working Group' under the East Asia-Australasian Flyway Partnership (EAAFP) - facilitates public participation in a number of ways including: empowering wetland and habitat reserve managers and providing them with 'opportunities for multinational cooperation in conservation'. ${ }^{148}$ Through the Network, researchers, government officials, NGOs and conservationists are encouraged to share their experiences through workshops and training courses (on education and visitor management). ${ }^{149}$ As Chan remarks, NEACSN has also run workshops on 'awareness of conservation issues, and training courses for local stakeholders'. ${ }^{150}$ Much of this would not have been possible without initial funding and support from the Japanese Government.

There is also some evidence that local governments in Japan have provided support for community involvement in wetland and birdlife protection. Tanaka's study of Man-ko (Okinawa), for example, found that local level management activities are 'basically done by the public-private collaborative networks initiated by local municipalities'. ${ }^{151}$ In the case of Hokkaido's Eastern Wetlands, the municipal government of Kushiro city has been historically active in protecting the wetlands and encouraging stakeholder participation in tancho conservation. For example, it has hosted events for the protection of the crane as well as the surrounding marshlands ${ }^{152}$ and, in 2011, facilitated the gifting of two cranes to the Taiwanese Government 'as a token of the Japanese people's gratitude for Taiwan's generous aid in the wake of the March [2011] earthquake and tsunami'. ${ }^{153}$ The gift was intended to 'help promote bilateral cooperation in the conservation of endangered animal species'. ${ }^{154}$

Likewise, the Akkeshi (Ramsar) site which is home to a 380 hectare sanctuary for the tancho, ${ }^{155}$ has enjoyed 'comprehensive environmental management' and 'significant citizen and stakeholder involvement ... encouraged and facilitated by the Town government'. ${ }^{156}$ As Kawabe remarks, the town's strategy has 'evolved from the 1970s from a broad regulatory strategy to a more site-specific one, shifting the approach from regulation to prevention'. ${ }^{157}$ The Akkeshi Town Government produces pamphlets about conservation of the wetlands, ${ }^{158}$ and, along with several other municipalities, it funds the

148. Ibid, 322.

149. Ibid.

150. Ibid, 320 .

151. Tanaka (n 71).

152. Simba Chan, 'Japan Crane Workshop marks Ramsar COP5 anniversary', Ramsar.org (10 December 2003) <http://www.ramsar.org/news/japan-crane-workshop-marks-ramsar-cop5anniversary $>$.

153. 'Delegation departs to obtain gift of rare cranes from Japan', The China Post (13 September 2011) <http://www.chinapost.com.tw/taiwan/foreign-affairs/2011/09/13/316495/Delegationdeparts.htm>.

154. Ibid.

155. Ministry of the Environment, Conservation and Wise Use of Rich and Diverse Wetlands: Ramsar Sites in Japan, online <http://www.env.go.jp/en/nature/npr/ramsar_wetland/pamph/ akkeshi_8.pdf> 14.

156. Fletcher (n 24) 959.

157. Midori Kawabe, 'Akkeshi: A Small Town's Coastal Zone Management Challenges' (21st International Conference of The Coastal Society).

158. East Asian-Australasian Flyway Partnership, Excursion Information field trip to Kushiroshitsugen wetland and Akkeshi-ko lake (Flyway Network Sites) <http://www.eaaflyway.net/word press/new/thepartnership/partners/meetingofpartners/mop8/Excursion\%20Information.pdf>. 
operation of the 'Kushiro International Wetland Centre' allowing it to 'collaborate [on] activities with central and local governments, NGOs and local specialists'. ${ }^{159}$

Despite these efforts, one of the major failings of the Japanese Government has been their lacklustre approach to including Japan's indigenous peoples (the Ainu) in conservation efforts. The most recent National Biodiversity Strategy, for example, fails specifically to mention a role for the Ainu at all. This is perhaps not surprising. As Maruyama has recently pointed out, despite the Ainu receiving formal (government) recognition in $2008,{ }^{160}$ the government has yet to take any firm steps 'toward protection of Ainu indigenous rights in Japan'. ${ }^{161}$ One of the core promises of the Ramsar framework is to improve inclusion and participation from indigenous peoples in wetland management, and this seems not to have occurred. Ignoring the Ainu overlooks the fact that they have played a prominent role in the tancho's survival to date. As Suzuki and others report (quoting Henry Lickers, a Native American ecologist): ' $[\mathrm{t}]$ he Ainu, the traditional people in northern Japan, they have a preserve that saves [the] crane that would've been wiped out if the government had tried to save it. The Ainu people still kill and eat it, but they also know how to keep its habitat going., ${ }^{162}$

There are some parts of Hokkaido where the cultural rights of the Ainu have been recognised and their viewpoints facilitated or at least protected. In 2007, for instance, the Saru River Basin (in Hokkaido's South) was declared a 'cultural landscape' of Japan. Yet on the other hand, the Lake Akan district, home to a Ramsar site, has long been inhabited by the Ainu people but no equivalent recognition exists. In the end, evidence of government-facilitated indigenous participation in wetland issues is not readily available. Their exclusion from the National Biodiversity Strategy seems particularly concerning, though these findings seem to resonate with Kimura's study in 2010: '[i]n Japan, the framework for cultural heritage management has almost exclusively been directed to preserving and promoting the common heritage of the Japanese nation state, with little recognition of the heritage interests of specific ethnic groups there, such as the Ainu. 163

Overall, the government's neglect of the Ainu in wetland conservation and wildlife management is problematic because it runs counter to one of Ramsar's key principles on the wise use of wetlands. It is all the more unfortunate because, as Matsui has argued, a convention like Ramsar has the potential to play a much stronger role in 'strengthening the security of indigenous people's cultural rights'. ${ }^{164}$

159. Wetland Link International, 'Kushiro International Wetland Centre' <http://www.wli.wwt. org.uk/2012/11/members/asia/asia-members/kushiro-international-wetland-centre-2/\#tab-2> and for the funding point, see Wetland Link International, 'Kushiro International Wetland Centre' $<$ http://www.wli.wwt.org.uk/2012/11/members/asia/asia-members/kushiro-international-wetlandcentre-2/\#tab-1>.

160. Philippa Fogarty, 'Recognition at last for Japan's Ainu,' BBC News (6 June 2008) <http:// www.news.bbc.co.uk/2/hi/asia-pacific/7437244.stm>.

161. Hiroshi Maruyama, 'Disregard for the conservation of Ainu culture and the environment: the Biratori Dam project and Japan's current policy toward the Ainu' (2013) 9(1) AlterNative 74.

162. David Suzuki and Holly Dressel, More Good News: Real Solutions to the Global EcoCrisis (Greystone Books; Vancouver, revised edition May 18 2010) 52.

163. Hidehiko Kimura, Tatsuo Nishijima, Hideki Yoshihara and Hirofumi Kato, 'Prospects for Ainu Management of Ainu Cultural Heritage and Landscape: A Proposed Collaboration with the Nibutani Community, Biratori, Hokkaido, Japan' (Statement Prepared for the IPinCH Case Study Workshop, October 2010) 1.

164. Kazuhiro Matsui, 'The influence of the Ramsar Convention on human rights treaties: with the conservation of indigenous people's culture' 8(2) International Public Policy Studies 67. 


\subsubsection{The role of civil society}

The role of the Japanese people in science and conservation issues has an interesting and lengthy history. As Miller-Rushing and others have pointed out, the Japanese have "been recording dates of the traditional cherry blossom festival for over 1,200 years' ${ }^{165}$ The practice is important chiefly because the flowering of the cherry blossom (sakura) has been used to help determine changes in seasonal temperature and the beginning of spring. ${ }^{166}$ These forms of community initiatives might be considered 'citizen science' in modern day terms, and, like the communities' role in protecting the tancho, reveal the special relationship between the presence of nature and the Japanese people's cultural practices and beliefs.

In the context of wetland and birdlife protection, there is evidence that local communities have played a significant and historical role. ${ }^{167}$ Indeed, there are several excellent case studies to draw on. For instance, at Saroma lake (Japan's third largest lake) researchers have found that participation from local stakeholders has benefited 'the socioeconomic development and the social and cultural wealth of the community'. ${ }^{168}$ In agricultural wetlands, near Sendai city, communities were active in establishing a Ramsar site through conservation education work. ${ }^{169}$ Tanaka's study of the Man-ko wetland (in Okinawa) found that most local level management activities were being undertaken by public-private networks with 'close collaboration between key stakeholders'. ${ }^{170}$ Moreover, there is the (rather) famous story of Toyooka City Wetlands where local villagers reintroduced the Oriental White Stork (which had become extinct in Japan in the 1970s) by creating 'artificial breeding habitat and reduc[ing] pesticide use in the rice paddies'. ${ }^{171}$ Finally, at the Yatsu Tidal Flat at Tokyo Bay, which is an important 'staging and wintering site for migratory waterbirds', NGOs and others are involved in 'helping to manage the site through preparation of the management plan, waste collection, water quality monitoring, and bird monitoring'. ${ }^{172}$

In respect of Eastern Hokkaido and the red-crowned crane, local communities (farmers and fisher people in particular) have also been involved in habitat rehabilitation and feeding and breeding endeavors. As noted above, the local community saved a dozen tancho from starvation in the early twentieth century and, since the 1950s, local farmers have fed and cared for the tancho by scattering grain during the harsh winters of Northern Japan. ${ }^{173}$ A recent report from National Geographic

165. Abraham Miller-Rushing, Richard Primack and Rick Bonney, 'The history of public participation in ecological research' (August 2012) 10(6) Citizen-Science Review 285.

166. Yasuyuki Aono and Yukio Omoto 'Variation in the March mean temperature deduced from cherry blossom in Kyoto since the 14th century' (1993) 48(5) J. Agr. Met. 635.

167. Nakamura et al (n 52).

168. Reiko Nakamura, 'Essentials of Stakeholder Participation in the Wise Use of Wetlands: Good Practices of Two Lagoons in Japan and India' in Jennifer Turner and Kenji Otsuka (eds), Promoting Sustainable River Basin Governance (Institute of Developing Economies, Chiba 2005) 151.

169. Hiromi Kobori, 'Current trends in conservation education in Japan' (2009) 142(9) Biological Conservation 1950.

170. Tanaka (n 71) 3.

171. 'Ramsar Implementation in Japan', Ramsar.org (14 May 2014) <http://www.ramsar.org/ news/ramsar-implementation-in-japan $>$.

172. Ramsar Convention Bureau (n 77) 78.

173. See National Geographic, 'Japan's Dancing Cranes'<http://www.nationalgeographic.org/ video/japans-dancing-cranes/>. 
noted that 'throughout the winter, [Hokkaido residents] go out of their way to feed these giant birds'. ${ }^{174}$ Volunteers on a farm in the wetlands also conduct an annual crane census. ${ }^{175}$ Perhaps these efforts are not particularly surprising in a country like Japan, which has a relatively long history of 'trying to keep nature and humanity in balance'. ${ }^{176}$ It may seem even less surprising when one considers the tremendous cultural significance of the tancho to Japanese custom and identity. Be that as it may, it does provide significant evidence of communities and residents taking an active role in supporting tancho survival.

In addition to local communities, many of the big international NGOs (BINGOs) have also played a crucial role in promoting wetland protection community participation at the international and domestic level in Japan. It is suggested in this paper that these behaviors can perhaps be traced to the historical involvement of NGOs in the development of Ramsar in the 1960s and 1970s (see part 3 above). Today, BirdLife International (BI); the International Water Management Institute (IWMI), Wetlands International (WI), the IUCN and WWF International have been formally recognized as 'official partners' of the Convention. ${ }^{177}$ National affiliates of the BINGOs have consistently worked with local communities, other NGOs, municipalities and national governments to improve habitat for birdlife and wetlands across Japan. Wetlands International (Japan), for example, has made a push to see local communities work together to create local wetland 'action plans' for each individual wetland. ${ }^{178}$ This goal seems to be aligned with the Ramsar Secretariat's aim of ensuring that states all have action plans in place 'at the national, sub-national, catchment or local levels'. ${ }^{179}$ WWF-Japan was involved in the development of the Ramsar handbook on public participation ${ }^{180}$ as well as a Status Survey and Conservation Action Plan for the crane in the mid-1990s. ${ }^{181}$

Japan's NGOs have also been prominent observers at Ramsar meetings. At the Lake Utonai Ramsar Site in 1993, plans for a river diversion were opposed by Hokkaido Nature Conservation Society (established in 1964) on behalf of several groups. ${ }^{182}$ The Wild Bird Society of Japan (WBSJ) notified the Ramsar Bureau that the 'River Diversion to be a major threat to Lake Utonai' pushing for a full impact assessment of the process. ${ }^{183}$ In another example, the Japanese-based NGO Japan Wetlands Action Network (JAWAN) has been working with WWF-Japan on recording migratory bird data, and other developments which impact on wetlands including to "establish a

174. Ibid, 2 minutes 37 seconds.

175. Peter Matthiessen, 'From the Archives: The Cranes of Hokkaido' Audubon (7 April 2014) $<$ http://www.audubon.org/magazine/from-archives-cranes-hokkaido-peter-matthiessen>.

176. Ministry of Foreign Affairs Japan, Japan's Official Development Assistance White Paper 2014 (2015) 79.

177. Ramsar Convention Secretariat, 'About the Ramsar Convention' <http://www.ramsar.org/ sites/default/files/documents/library/about_nfp_2014_en.pdf>.

178. Japan NGO Network for Ramsar COP10, 'For the Protection of Wetland Biodiversity An Examination of Wetland Policy in Japan', Ramsar COP10 Japan Information Packet (20 October 2008).

179. Ramsar Convention Bureau, Handbook 6 Wetland CEPA (Ramsar Convention Secretariat, Gland 2010) 5.

180. Ramsar Convention Bureau (n 77).

181. Meine and Archibold (n 9).

182. Ramsar Convention on Wetlands, 5th Meeting of the Conference of the Contracting Parties, Kushiro, Japan 9-16 June 1993: Summary Reports of the Workshops (May 2000).

183. Ibid. 
wider coalition of NGOs' working on wetland conservation in Japan. ${ }^{184}$ Moreover, the Ramsar Network Japan (RNJ) began around the same time and is said to 'cooperate closely with grassroots NGOs' in the management of Ramsar sites. ${ }^{185}$ There is also a 'Citizens' Association to Increase Ramsar Sites in Japan', organised in 2006, which aims to 'promote designation of Ramsar Sites in Japan from the standpoint of citizens, and to disseminate and implement conservation and wise use of wetland ecosystems, the fundamental idea of the Convention'. ${ }^{186}$

NGOs concerned specifically with the protection of birds worldwide appear also to have actively been involved in conservation efforts. BirdLife International's Asia Division, for instance, reportedly undertakes considerable on-the-ground work in Japan and other parts of Asia. ${ }^{187}$ The International Crane Foundation (ICF) has been actively involved in the monitoring and health of cranes since the 1970s. Their website reports an impressive contribution including conducting surveys and Japanese colleagues working alongside Korean and Russian colleagues. The ICF also worked to establish Russia's first private nature reserve for cranes ${ }^{188}$ and played a pivotal role in establishing the North East Asian Crane Site Network (see above) which aims to share experiences in participatory management across China, Russia, Korea, Mongolia and Japan. ${ }^{189}$

\subsubsection{The role of the private sector}

Business and commercial institutions are also major non-state actors in environmental governance today. Japan has sought to improve commercial initiatives for protecting biodiversity and habitat across the country. The Japan Business Initiative for Biodiversity (JBIB), for example, was established in 2008, and is comprised of Japanese corporations which are 'committed to biodiversity conservation' including wetland management. ${ }^{190}$ Through the JBIB, MS\&AD Holdings—a Japanese insurance and financial company-has launched 'biodiversity conservation activities with a focus on wetlands' including having its employees engage in volunteer activities. ${ }^{191}$ JBIB has also partly supported the restoration of wetlands at Tohoku in Japan. ${ }^{192}$

There is also the 'Japan Business and Biodiversity Partnership' whose membership includes public agencies and NGOs as well as over 400 of Japan's biggest companies

184. Ramsar Network of Japan, 'Terms of Reference Ramsar Network Japan' (April 2010) $<$ http://www.ramnet-j.org/2010/09/14/rnj_tor_2010815.pdf > .

185. Ibid.

186. Citizens' Association to Increase Ramsar Sites $<$ http://www.tml.co.jp/ramnet/pdf/ramshiminpos.pdf>.

187. BirdLife International Asia Division, Annual Report 2013 (Tokyo, 2013) <http://www. tokyo.birdlife.org/eng/pdf/ar2013en.pdf>.

188. International Crane Foundation Species Field Guide (n 121).

189. Chan (n 17).

190. Japan Business Initiative for Biodiversity (JBIB), 'JBIB Overview' <http://www.jbib.org/ english/introduction>.

191. MS\&AD Holdings, 'Preservation of Biodiversity' <http://www.ms-ad-hd.com/en/csr/ earth/creature.html>.

192. Tsubasa Iwabuchi, 'Tohoku Green Renaissance Projects - Rebuilding from 3.11 Disaster' Presentation (unpublished) <http://www.satoyama-initiative.org/wp-content/uploads/2012/03/ Tohoku-University_Tsubasa-Iwabuchi.pdf>. 
across a range of fields from steel to design to motor vehicles, banking and electronics. ${ }^{193}$ A report from the initiative in 2014 showcased several initiatives aimed at conserving biodiversity, including a project by Ricoh (a Japanese electronics company) which created 'an educational pond to reproduce and reintroduce a wetland'. ${ }^{194}$

In other instances, NGOs have directly partnered with businesses in Japan to improve conservation awareness, including, for example, a collaboration between Mitsubishi Heavy Industries (MHI) Ltd and BirdLife International. In 2012, MHI-one of Japan's largest corporate enterprises-invited BirdLife International to conduct biodiversity education for environmental managers at its manufacturing bases in Japan. In addition, MHI asked BirdLife International (Tokyo branch) 'to conduct an evaluation of [their] corporate biodiversity activities'. ${ }^{195}$ There are several other examples of corporate support as well, including private initiatives specifically directed towards conservation of the tancho. In 2011, the Japanese camera company Canon donated US\$17,000 to help support the red-crowned cranes gifted by Kushiro to the Taiwanese Government (see above) as gratitude for the 2011 tsunami relief. ${ }^{196}$ Likewise, the camera manufacturing company Konica Minolta raises awareness for children about the tancho on its website through simple storylines. ${ }^{197}$ Finally, another well-known Japanese corporation, Fujitsu, has partnered with the Wild Bird Society of Japan to help conduct 'remote monitoring studies to examine the effectiveness of natural feeding grounds [for the tancho]' ${ }^{198}$ The point is simply that profit-seeking private entities in Japan can (and have) played a role in biodiversity conservation and protection of endangered species like the tancho.

\section{CONCLUSION}

The legal principle of public participation has been narrowly construed as mere 'involvement' by non-state actors in environmental decision-making. Either knowingly or otherwise, the Ramsar Convention framework has enlarged the principle (or created a new one) to include 'participatory management' whereby stakeholders have a right to play a hands on role in restoring wetlands and protecting birdlife. This paper has sought to explore the connections between civil society, birdlife and Ramsar wetlands in Japan. The case study presented showed both state and nonstate actors working remarkably well to help protect and conserve the red-crowned crane in northern Japan. Over a century ago, fewer than 20 red-crowned cranes existed in Japan, today they number over 1,000. These successes would not have occurred if it were not for the initiative of the public, NGOs, Indigenous Peoples

193. Japan Business and Biodiversity Partnership, 'The List of Members of "Japan Business and Biodiversity Partnership"" <http://www.bd-partner.org/english/list/>.

194. Japan Business Initiative for Biodiversity, JBIB Brochure available at <http://www.jbib. org > (Tokyo, 2014).

195. Mitsubishi Heavy Industries Group, 'CSR Initiatives For the Year Ended 31 March 2014' <http://www.mhi.com/company/csr/library/pdf/csrdatabook2014_all.pdf>.

196. 'Japan's Canon makes donation to help nurture rare birds in Taipei', The China Times (30 October 2011) <http://www.thechinatimes.com/online/2011/10/1779.html>.

197. Konica Minolta, 'Our Endangered Animals'<https://www.konicaminolta.com/kids/ endangered_animals/library/sky/rc-crane.html>.

198. Fujitsu Limited, 'Annual Report 2012' <http://www.fujitsu.com/downloads/IR/annual/ 2012/18.pdf> 69 . 
and other stakeholders taking an interest in the crane's survival. ${ }^{199}$ More recently, municipal governments in Japan and collaborating mechanisms (like the RCM) have created the conditions which allow communities to stay involved in wetland and birdlife protection.

The experience in Hokkaido has relevance for the populations of red-crowned cranes in Russia, China, Mongolia and Korea, though there are likely to be several points of difference. First, local Hokkaido communities (including the Ainu) had an established cultural connection with the tancho well before Ramsar and the principle of participation had been developed. Such relationships are likely to differ significantly in crane habitats in Korea and China. Second, the population of cranes in Korea, China and Russia are migratory and thus cross-cultural and diplomatic factors will play a stronger role than in the Japanese example (where the population is constant). Their survival depends on cooperation across borders, in remote areas, and in an uncertain geo-political environment. Third, poorer communities in Mongolia, Russia and parts of rural China may find it difficult to engage actively with participatory strategies. It has been found in the case of Brazil, for instance, that where education levels in the community are low, there is little involvement or interest in 'political' and 'ecological' aspects of conservation. ${ }^{200}$ Finally, there may be considerable pro-development burdens to overcome. In Korea, for instance, Ramsar sites have traditionally 'not [been] welcomed by local communities as they are seen as a hindrance to local development' ${ }^{201}$ Rural and coastal China may find similar sentiments.

In the end, further case studies about public participation, birdlife and the Ramsar framework are needed, particularly taking account of the behavior of non-state actors (NGOs, communities, private enterprise, etc). As made clear at the outset, nature is intimately connected to culture in ways we are only just beginning to understand. Communities and the general public need to be legitimized and empowered through the law to drive positive environmental change. Ramsar's model of participatory management is a strong one, and the case presented above provides ample evidence of how participation can, and perhaps should, work if we are to reverse declines in both wetlands and birdlife in East Asia.

199. It is also likely that they would not have occurred for lesser-known bird species that, for whatever historical and cultural reasons, lack the iconic status of the tancho.

200. Debora Calheiros, 'Baía do Castelo: Local Community Participation in the Upper Paraguay River Basin, Pantanal Wetland, Mato grosso do Sul State', Commissioned for the Project in Response to Ramsar Recommendation 6.3, 7.

201. Mauerhofer et al (n 25) 99. 